\title{
Identification of conserved antigens for early serodiagnosis of relapsing fever Borrelia
}

\section{Correspondence \\ Job Lopez \\ lopezjob@niaid.nih.gov}

Received 27 April 2009

Revised 8 May 2009

Accepted 12 May 2009

\author{
Job E. Lopez, ${ }^{1}$ Stephen F. Porcella, ${ }^{2}$ Merry E. Schrumpf, ${ }^{1}$ \\ Sandra J. Raffel, ${ }^{1}$ Carl H. Hammer, ${ }^{3}$ Ming Zhao, ${ }^{3}$ Mary Ann Robinson ${ }^{3}$ \\ and Tom G. Schwan ${ }^{1}$
}
${ }^{1}$ Laboratory of Zoonotic Pathogens, Rocky Mountain Laboratories, National Institute of Allergy and Infectious Diseases, National Institutes of Health, Hamilton, MT 59840, USA
${ }^{2}$ Research Technologies Section, Research Technologies Branch, Rocky Mountain Laboratories, National Institute of Allergy and Infectious Diseases, National Institutes of Health, Hamilton, MT 59840, USA
${ }^{3}$ Research Technologies Section, Research Technologies Branch, National Institute of Allergy and Infectious Diseases, National Institutes of Health, Rockville, MD 20852-1737, USA

\begin{abstract}
Borrelia hermsii is a blood-borne pathogen transmitted by the argasid tick Ornithodoros hermsi. Since spirochaete clearance in mice is associated with an IgM-mediated response, an immunoproteomic analysis was used to identify proteins reactive with $\lg M$. We report that $\lg M$ from both mice and human patients infected with $B$. hermsii not only reacted with the previously identified variable membrane proteins but also identified candidate antigens including heat-shock proteins, an adhesin protein, $\mathrm{ABC}$ transporter proteins, flagellar proteins, housekeeping proteins, an immune evasion protein, and proteins with unknown function. Furthermore, IgM reactivity to recombinant glycerophosphodiester phosphodiesterase was detected during early spirochaete infection and prior to a detectable lgG response. Lastly, a conserved hypothetical protein was produced in Escherichia coli and tested with immune serum against $B$. hermsii and Borrelia recurrentis. These results identify a much larger set of immunoreactive proteins, and could help in the early serodiagnosis of this tick-borne infection.
\end{abstract}

\section{INTRODUCTION}

Relapsing fever spirochaetes in the genus Borrelia are bloodborne pathogens distributed throughout much of the world (Barbour \& Hayes, 1986; Felsenfeld, 1971; Southern \& Sanford, 1969). The spirochaetes are transmitted by either ticks or the human body louse, and other than Borrelia duttonii and Borrelia recurrentis, which are transmitted between humans (Burgdorfer, 1951; Buxton, 1946), the most common vertebrate hosts for the spirochaetes are small rodents (Dworkin et al., 2002; Schwan \& Piesman, 2002). During mammalian infection, a family of immunogenic variable membrane proteins undergo antigenic variation, allowing for immune evasion, recurrent spirochaetaemia, and persistence in the blood (Barbour, 1990; Barbour et al., 2006; Dai et al., 2006; Hayes et al., 1988; Restrepo et al., 1992; Stoenner et al., 1982). Interestingly, each spirochaetaemic

Abbreviations: GlpQ, glycerophosphodiester phosphodiesterase; rGlpQ, recombinant glycerophosphodiester phosphodiesterase.

The GenBank/EMBL/DDBJ accession numbers for the nucleotide sequences for the genes located on $B$. hermsii plasmids, and whose sequences have not previously been deposited in the GenBank database, are FJ446702 (oppAIV) and FJ446703 (hypothetical protein) episode is rapidly cleared from the blood by a robust T-cellindependent response involving expansion of IgM-secreting B1b and marginal zone B cells (Alugupalli et al., 2003a, b, 2004; Alugupalli, 2008; Barbour, 1990; Barbour \& Bundoc, 2001; Belperron et al., 2005; Newman \& Johnson, 1984; Stoenner et al., 1982).

Relapsing fever Borrelia can reach upwards of $10^{7}$ spirochaetes per $\mathrm{ml}$ of infected blood (Bryceson et al., 1970; Coffey \& Eveland, 1967), and can be detected by microscopy. However, detection by microscopy lacks sensitivity between spirochaetaemic episodes. Glycerophosphodiester phosphodiesterase (GlpQ) has been used as a diagnostic antigen for infection with relapsing fever spirochaetes in North America and Africa (Nordstrand et al., 2007; Porcella et al., 2000; Schwan et al., 1996). However, in one report $79 \%$ of Ethiopian patients infected with $B$. recurrentis did not have detectable $\operatorname{IgG}$ responses to recombinant GlpQ (rGlpQ) during early spirochaete infection as determined by an ELISA (Porcella et al., 2000).

With variable membrane proteins facilitating immune evasion, and the robust IgM-mediated response during early infection, understanding the broader antigenic 
repertoire against conserved proteins is important. However, little is known about proteins reactive with IgM in relapsing fever spirochaetes (Anda et al., 1996; Colombo \& Alugupalli, 2008; Connolly et al., 2004). In this study, protein candidates reactive with IgM were identified using serum from mice and human patients infected with Borrelia hermsii. The amino acid identity of Borrelia orthologues was compared to B. hermsii, and early IgM responses to rGlpQ were determined using serum samples from Ethiopian patients that had previously tested negative to rGlpQ during early spirochaete infection (Porcella et al., 2000). Furthermore, a hypothetical protein from B. hermsii was produced and the immunogenicity of this recombinant protein was tested as a possible diagnostic antigen.

\section{METHODS}

Animal inoculation and immune sera collection. Low-passage $B$. hermsii DAH isolate was grown in BSK medium containing $12 \%$ rabbit serum (Barbour, 1984; Battisti et al., 2008) to $1.0 \times 10^{8}$ spirochaetes $\mathrm{ml}^{-1}$, and used to needle inoculate three mice intraperitoneally with $1.0 \times 10^{5}$ spirochaetes per mouse. Prior to, and for the first 4 days and the seventh day after inoculation, blood was obtained, and the spirochaetaemias were quantified by brightfield microscopy (Schwan et al., 2003). Immune serum collected from the mice was pooled. All animal handling was in compliance with the Rocky Mountain Laboratories Animal Care and Use Committee.

Human serum was available from two patients who were infected with $B$. hermsii. Serum samples from both patients were collected within 1 month of the initial spirochaetaemic episode. Serum samples from patients infected with $B$. recurrentis were available from a hospital in Addis Ababa, Ethiopia, as previously described (Porcella et al., 2000). The acute-phase serum samples were collected shortly after hospitalization; the convalescent-phase serum samples were collected 8-13 days later. Acute-phase serum samples used in this study had tested IgG negative to $\mathrm{rGlpQ}$ while convalescent-phase samples were positive (Porcella et al., 2000).

Sample preparation, 2D electrophoresis and 2D immunoblotting. Low-passage (passage seven) B. hermsii DAH was grown in mBSK medium containing 12\% rabbit serum (Barbour, 1984; Battisti et al., 2008) and harvested when the spirochaetes were at approximately $1.0 \times 10^{8}$ spirochaetes $\mathrm{ml}^{-1}$. For all sample preparations, spirochaete concentrations were standardized by adjusting each preparation to $\mathrm{OD}_{600} 0.2$ in $1 \times \mathrm{PBS}$ containing $5 \mathrm{mM} \mathrm{MgCl}_{2}$, which is approximately $7.22 \times 10^{7}$ spirochaetes $\mathrm{ml}^{-1}$. Samples were then centrifuged at $9000 \mathrm{~g}$ for $15 \mathrm{~min}$ at $4{ }^{\circ} \mathrm{C}$, concentrated eightfold with $1 \times$ PBS containing $5 \mathrm{mM} \mathrm{MgCl}_{2}$ and Complete Mini EDTA-free protease inhibitors (following manufacturer's instructions) (Roche Diagnostics) to approximately $5.8 \times 10^{8}$ spirochaetes $\mathrm{ml}^{-1}$.

The $5.8 \times 10^{8}$ spirochaetes were centrifuged at $13000 \mathrm{~g}$ for $5 \mathrm{~min}$ and processed through the ReadyPrep Protein Extraction kit (Soluble/ Insoluble) (Bio-Rad), following the manufacturer's instructions. After protein extraction, samples were resuspended in $100 \mu \mathrm{l} 2 \mathrm{D}$ Rehydration Sample Buffer 1 (Bio-Rad) containing $2 \mathrm{mM}$ tributylphosphine (TBP) (Bio-Rad) and $0.2 \%$ ampholytes (Bio-Rad). Samples were precipitated using the ReadyPrep 2-D Cleanup kit (Bio-Rad), following the manufacturer's instructions.

Soluble and insoluble fractions were resuspended in $200 \mu \mathrm{l} 2 \mathrm{D}$ Rehydration Sample Buffer 1 containing $2 \mathrm{mM} \mathrm{TBP}$ and $0.2 \%$ ampholytes, and used to rehydrate $11 \mathrm{~cm} \mathrm{pH} \mathrm{4-7,} \mathrm{pH} \mathrm{5-8,} \mathrm{or} \mathrm{pH} \mathrm{7-}$ 10 ReadyStrip IPG Strips (Bio-Rad). Rehydration was performed under active conditions, and IPG strips were focused for a total of $25000 \mathrm{~V}$ h using the PROTEAN IEF (Bio-Rad).

IPG strips were equilibrated for $20 \mathrm{~min}$ as specified by the manufacturer (Bio-Rad) with equilibration buffer 1 containing $5 \mathrm{mM}$ TBP. IPG strips were transferred onto $10.5-14 \%$ Criterion Precast Gels (Bio-Rad), electrophoresed, and stained with the colloidal Coomassie SimplyBlue SafeStain (Invitrogen) or transferred onto a nitrocellulose membrane using the iBlot Dry Blotting System (Invitrogen).

Mouse serum samples collected prior to and 7 days after infection, and immune serum from human patients infected with $B$. hermsii, were used to probe $2 \mathrm{D}$ immunoblots at a 1:100 dilution in I-Block blocking reagent (TROPIX). Secondary mAbs were goat anti-mouse IgM-HRP (Invitrogen) at 1:4000 or goat-anti-human IgM-peroxidase (Sigma-Aldrich) at 1:20000. Membranes were developed by chemiluminescence with the ECL Western Blotting Detection Reagent (GE Healthcare), following the manufacturer's instructions. Images from $2 \mathrm{D}$ gels and 2D immunoblots were acquired with the GelDoc (Bio-Rad), and overlaid in order to select IgM-reactive protein spots.

2D gel protein sample preparation for mass spectrometry. Protein samples of interest were excised from colloidal Coomassiestained (Invitrogen) gels using the 1.0, 2.0, or $3.0 \mathrm{~mm}$ Harris UniCore sampling punch tool (Sigma-Aldrich) and placed into a new Ultra Low Attachment 96-well Costar Plate (Corning Inc.). Gel plugs were destained, reduced, alkylated, and then rehydrated in $25 \mu \mathrm{l}$ of $10 \mathrm{ng}$ $\mu^{-1}$ sequencing grade trypsin solution (Promega).

After an overnight incubation at $37^{\circ} \mathrm{C}$, supernatants containing eluted trypsinized peptides were removed and placed into a new Ultra Low Attachment 96-well Costar Plate. Peptides were further extracted by adding $5 \%$ formic acid (Sigma-Aldrich) and $50 \%$ acetonitrile (ACN) to the gel plugs for $30 \mathrm{~min}$ at $37^{\circ} \mathrm{C}$. The solution was removed and pooled with the supernatants from the overnight trypsinization and the extraction repeated. Trypsinized peptides were dried under vacuum (Jouan) and dissolved in $30 \mu \mathrm{l}$ of $0.1 \%$ trifluoroacetic acid (TFA) (JT Baker).

Peptide samples were desalted with the C18 ZipTips (Millipore), following the manufacturer's instructions with minor modifications. Briefly, ZipTips were conditioned with $90 \%$ methanol and $0.1 \%$ TFA, equilibrated with $0.1 \%$ TFA, and peptides bound by pipetting. Peptides were washed with $0.5 \%$ acetic acid (Sigma-Aldrich), eluted into a Thermo-Fast 96-well skirted plate (ABgene House) with $70 \%$ $\mathrm{ACN}$ and $1 \%$ acetic acid, and dried under vacuum centrifugation for mass spectrometric analysis.

Mass spectrometry, B. hermsii database search, and basic local alignment search tool (BLAST) analysis. Identification of proteins from $2 \mathrm{D}$ gels was performed by mass spectrometry, and this was repeated four separate times. Tryptic digests were analysed by coupling the Nanomate (Advion BioSciences), an automated chipbased nano-electrospray interface source, to a quadrupole-time of flight mass spectrometer, QStarXL MS/MS System (Applied Biosystems/ Sciex). Peptide sequence information was provided by MS/MS. AnalystQS software (Applied Biosystems/Sciex) was used for data acquisition. Data processing and database searching were performed with the MASCOT software (Matrix Science). A protein database was generated from the genome sequence of $B$. hermsii DAH and submitted to MASCOT as a separate database for searching. Generally, MASCOT ion scores greater than 24 correspond to a probability of $95 \%$ or greater that the peptide match is not a random event.

To determine the amino acid identity of non-variable membrane proteins, protein BLAST analysis was performed at http://blast. ncbi.nlm.nih.gov/Blast.cgi. Also, individual variable small proteins (Vsps) and variable large protein (Vlp) 5 were named according to 

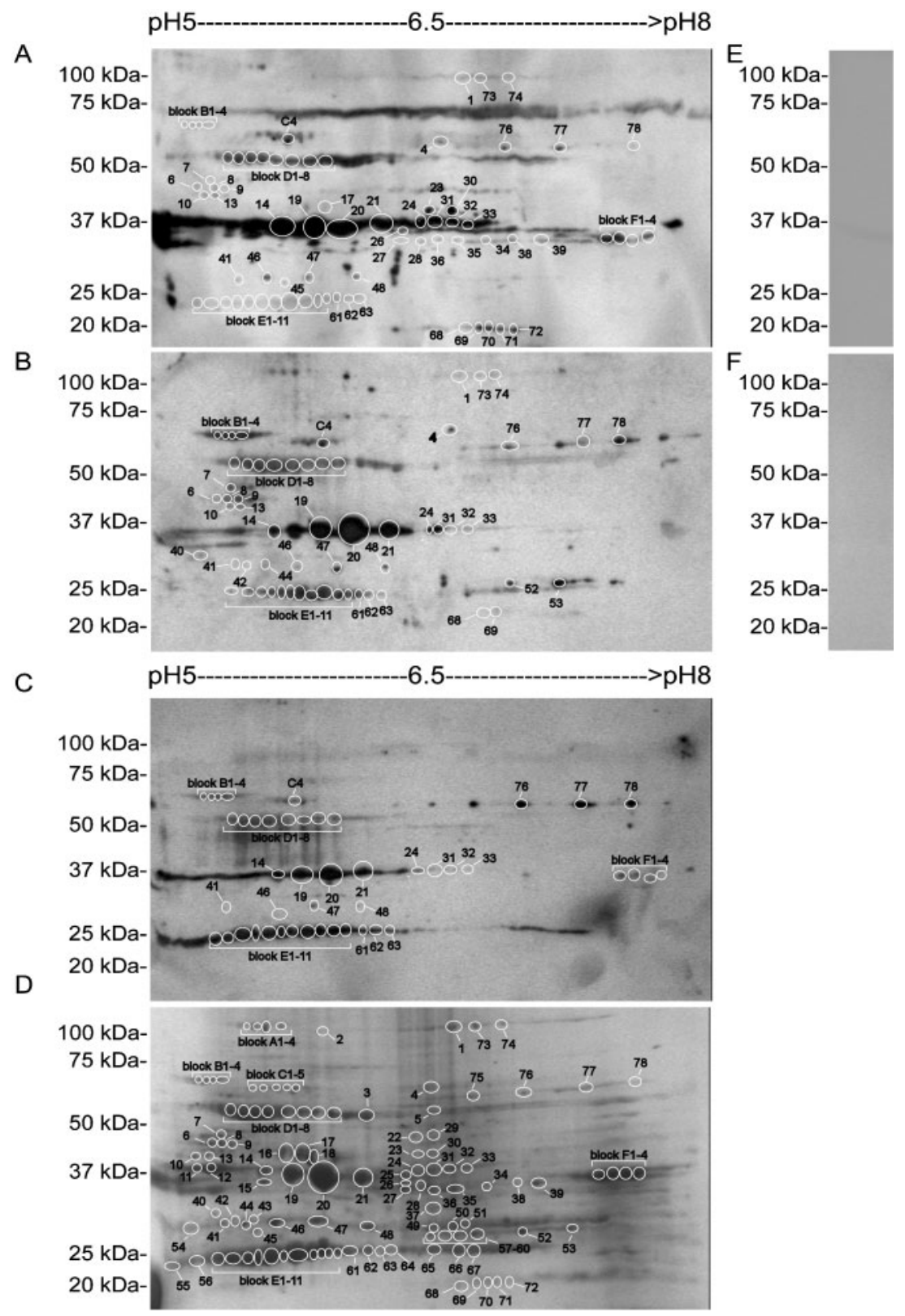

Fig. 1. $2 \mathrm{D}$ immunoblots $(\mathrm{A}-\mathrm{C})$ and a Coomassie stained gel (D) of $B$. hermsii lysate. Serum samples from three mice infected with $B$. hermsii were collected, pooled, and used to probe immunoblots $(A)$. Serum from patient 1 (B) and patient 2 (C) was collected after $B$. hermsii infection. Proteins identified by mass spectrometry from $2 \mathrm{D}$ gels are numbered on 2D immunoblots $(A-C)$. 1D immunoblots confirmed that murine pre-immune sera (E) and human serum from an uninfected donor were negative to $B$. hermsii whole-cell lysate (F). Molecular mass standards are shown on the left.

BLAST analysis. A BLAST threshold $E$-value of $1.0 \times 10^{-4}$ was used to identify borrelia proteins.

Production of rGIpQ and recombinant BH0238 (rBH0238). $B$. hermsii and $B$. recurrentis $g l p Q$ were expressed as previously described (Porcella et al., 2000; Schwan et al., 2003). Genomic DNA from B. recurrentis 115 and $B$. hermsii DAH was used to amplify $g l p Q$. glpQ was expressed as a His-tagged fusion protein in the pET-15b (Novagen) and pET-32a (Stratagene) expression vectors for $B$. recurrentis and $B$. hermsii, respectively, following the manufacturer's instructions.

bh0238 was expressed using the pBAD/TOPO ThioFusion expression system following the manufacturer's instructions (Invitrogen). Forward and reverse primers used to amplify bh0238 from B. hermsii DAH genomic DNA were 5'-ATGACTAGATTTTTAGTGGAGGTTAGCATGAG-3' and 5' $^{\prime}$-TTTTATTGAAAAGAGTACCCATTTATCATCC-3', respectively. PCR amplification consisted of 34 cycles with a denaturing temperature of $94{ }^{\circ} \mathrm{C}$ for $30 \mathrm{~s}$, annealing temperature of $55{ }^{\circ} \mathrm{C}$ for $30 \mathrm{~s}$, and an extension temperature of $72{ }^{\circ} \mathrm{C}$ for $2.5 \mathrm{~min}$. After confirming the correct orientation and nucleotide sequence within the $\mathrm{pBAD} / \mathrm{TOPO}$ ThioFusion vector using the Vector NTI software package (Invitrogen), bh0238 was induced with a final concentration of $0.2 \%$ arabinose and purified using a His-Bind Quick Column (Novagen) following the manufacturer's instructions.

1D SDS-PAGE and 1D immunoblotting. For detecting anti-GlpQ Abs during early mouse infection, whole-cell lysates of $B$. hermsii DAH, $6 \mu \mathrm{g}$ His-tagged rGlpQ (Schwan et al., 2003), and Escherichia coli containing the empty shuttle vector were separated by 1D SDSPAGE as previously described (Schwan et al., 1989) and transferred to a nitrocellulose membrane as stated above. Murine immune sera collected for the first 4 days post-inoculation were used at a dilution 
Table 1. IgM-reactive proteins identified by mass spectrometry

\begin{tabular}{|c|c|c|c|c|}
\hline Protein annotation & Spot & NCBI ID & Pred $\mathrm{MM}^{*}$ & MASCOT ion score $\dagger$ \\
\hline \multicolumn{5}{|l|}{ Heat-shock proteins } \\
\hline DnaK & B1-B4 & BH0518 & 68.7 & $274-482$ \\
\hline HtpG & $\mathrm{C} 4$ & BH0560 & 71.3 & $27-71$ \\
\hline GroEL & D1-D3 & BH0649 & 60.0 & $150-316$ \\
\hline \multicolumn{5}{|l|}{ Adhesin } \\
\hline P66 & $76-78$ & BH0603 & 66.0 & $60-462$ \\
\hline \multicolumn{5}{|l|}{$\mathrm{ABC}$ transporter proteins } \\
\hline OppA $\ddagger$ II & D5-D8 & BH0329 & 60.5 & $39-91$ \\
\hline OppA $\ddagger$ IV & $70-72$ & FJ446702 & 20.5 & $41-191$ \\
\hline Nucleoside-binding protein & $2-5 \S$ & BH0383 & 37.2 & $68-85$ \\
\hline Zn-binding protein & 42,44 & BH0713 & 29.5 & 35,86 \\
\hline \multicolumn{5}{|l|}{ Flagellar proteins } \\
\hline Flagellin & $14,19,20,21$ & BH0147 & 35.5 & $91-618$ \\
\hline Flagellar basal-body rod protein & 40 & BH0774 & 28.7 & 77 \\
\hline \multicolumn{5}{|l|}{ Housekeeping proteins } \\
\hline Enolase & $6-9,13$ & BH0337 & 47.4 & $122-341$ \\
\hline Cell-division protein FtsZ & 10 & ВH0299 & 43.6 & 67 \\
\hline GAPDHII & $\mathrm{F} 1-\mathrm{F} 4$ & BH0057 & 36.2 & $150-571$ \\
\hline GlpQS & $24,31-33$ & ВH0241B & 39.0 & $78-367$ \\
\hline Ef-Tu & $17,23,30$ & ВH0476 & 43.4 & $41-375$ \\
\hline Fructose-bisphosphate aldolase & 27 & BH0445 & 40.0 & $33-41$ \\
\hline Triosephosphate isomerase & 45 & BH0055 & 27.7 & 211 \\
\hline Phosphoglycerate mutase & 52,53 & BH0658 & 28.5 & $206-323$ \\
\hline \multicolumn{5}{|l|}{ Variable membrane proteins } \\
\hline Variable large protein 5 & $26,28,34-36,38,39$ & ABF21151 & 34.8 & $153-443$ \\
\hline Variable large protein C54silD & $12 \S, 13 \S$ & ABF82211 & 35.0 & $192-288$ \\
\hline Variable small protein 3 precursor & E1-E11 & AAA22967 & 18.6 & $167-318$ \\
\hline Variable small protein 22 silD & E1-E11 & ABF82176 & 23.0 & $48-77$ \\
\hline Variable small protein 6 & $\mathrm{E} 1, \mathrm{E} 2, \mathrm{E} 4, \mathrm{E} 5$ & AAZ94628 & 23.0 & $31-86$ \\
\hline Variable small protein 8 precursor & E1, E3-E5 & AAA59225 & 23.0 & $61-98$ \\
\hline Variable small protein 58 & E3 & ABE73350 & 23.0 & 80 \\
\hline Variable small protein 2 precursor & E3-E5 & AAF73948 & 23.0 & $60-71$ \\
\hline Variable tick protein & $61-63$ & AAT99985 & 21.0 & $172-291$ \\
\hline \multicolumn{5}{|l|}{ Immune evasion protein } \\
\hline Factor H-binding protein & 68,69 & EF411143 & 21.6 & $38-153$ \\
\hline \multicolumn{5}{|l|}{ Proteins with unknown function } \\
\hline Hypothetical & 4 & FJ446703 & 56.7 & 32 \\
\hline Hypothetical & $41,46,47,48$ & BH0238 & 30.6 & $33-369$ \\
\hline P93 & $1,73,74$ & BH0744 & 96.3 & $94-98$ \\
\hline
\end{tabular}

${ }^{*}$ Predicted molecular mass given in $\mathrm{kDa}$.

$\dagger$ MASCOT scores given are a low and high range for a respective protein. Scores above 24 are statistically significant with $P<0.05$.

$\ddagger$ Oligopeptide permease homologue.

\$Protein plug numbers in a 2D gel with an isolelectric focusing range of $\mathrm{pH} 4-7$.

IIGlyceraldehyde-3-phosphate dehydrogenase.

SGlycerophosphodiester phosphodiesterase.

of $1: 100$ to probe immunoblots. To differentiate between IgM and IgG responses, goat-anti-mouse IgM-HRP or HRP-recombinantProtein A (ZYMED) were used at a $1: 4000$ dilution.

rBH0238 produced in the $\mathrm{pBAD} / \mathrm{TOPO}$ ThioFusion system (Invitrogen) was examined as follows. E. coli harvested prior to and $2 \mathrm{~h}$ after induction or $B$. recurrentis lysate and $2 \mu \mathrm{g}$ of purified rBH0238 were separated by SDS-PAGE (Schwan et al., 1989), and stained with the colloidal Coomassie SimplyBlue SafeStain
(Invitrogen) or transferred onto a nitrocellulose membrane as stated above. Immunoblots were probed with a monoclonal anti-polyhistidine peroxidase conjugate (Sigma-Aldrich) at a $1: 2000$ dilution, immune serum from mice infected with $B$. hermsii at a $1: 100$ dilution, or acute and convalescent serum from Ethiopian patients infected with $B$. recurrentis at a 1:500 dilution. The secondary molecule used was HRP-recombinant-Protein A (ZYMED). In addition, convalescent-phase serum samples were used to determine seroconversion $\mathrm{rBH} 0238$. 
ELISA with rGIpQ. IgM reactivity to rGlpQ was determined by ELISA as previously described, with minor modifications (Porcella et al., 2000). Sera from Ethiopian patients infected with B. recurrentis were available from their acute phase of infection. Immune and negative control sera were diluted $1: 100$ in diluent $(1 \times \mathrm{PBS}, 5 \%$ horse serum, $0.05 \%$ Tween $20,0.001 \%$ dextran sulfate) and tested in triplicate. IgM binding to $\mathrm{rGlpQ}$ was determined using goat-antihuman IgM-peroxidase (Sigma-Aldrich) at 1:20000 followed by the addition of a substrate consisting of $50 \%$ 2,2'-azino-di-(3-ethylbenzthiazoline sulfonate). After $30 \mathrm{~min}$ incubation, the $A_{405}$ was measured with a Labsystems Multiskan Plus microtitre plate reader (Fisher Scientific). Samples were considered positive if their mean absorbance was more than three standard deviations above the mean of negative control serum samples.

\section{RESULTS}

\section{Evaluation of mouse and patient serum samples infected with $B$. hermsii}

All mice inoculated with $B$. hermsii DAH became spirochaetaemic within 3 days after injection (data not shown). IgM from these mice and patients infected with $B$. hermsii recognized antigens ranging from 20 to $100 \mathrm{kDa}$ (Fig. 1A-C), while murine preimmune sera or sera from uninfected human patients had little reactivity to $B$. hermsii whole-cell lysate (Fig. 1E and F).

\section{Protein spot selection for mass spectrometry}

Image overlays from 2D electrophoresis gels and 2D immunoblots probed with immune serum from mice or humans identified 114 protein candidates for mass spectrometry analysis within the isoelectric focusing range of $\mathrm{pH} 5-$ 8 (Fig. 1A-D). Vsps, Vlp 5, and the nucleoside-binding proteins were the only IgM-reactive proteins identified in $\mathrm{pH} 4-7$ and $\mathrm{pH}$ 7-10 2D gels (data not shown), and of these proteins, Vlp C54silD and the nucleoside-binding protein were the only additional proteins not identified in the $\mathrm{pH}$ range 5-8 (Table 1). Also, there were no apparent differences between protein fractions that were tested by $2 \mathrm{D}$ electrophoresis and immunoblotting.

Table 2. Percentage amino acid identity of Borrelia orthologues compared to $B$. hermsii

\begin{tabular}{|c|c|c|c|c|}
\hline Protein annotation & B. burgdorferi & B. recurrentis & B. duttonii & B. turicatae \\
\hline DnaK, BH0518 & 92 & 96 & 96 & 98 \\
\hline GroEL, BH0649 & 92 & 95 & 95 & 97 \\
\hline \multicolumn{5}{|l|}{ Adhesin } \\
\hline P66, BH0603* & 55 & 66 & 66 & 79 \\
\hline OppA† II, BH0329 & 65 & 79 & 79 & 82 \\
\hline OppA† IV, FJ446702 & 47 & 72 & 72 & 78 \\
\hline Nucleoside-binding protein, $\mathrm{BH} 0383$ & 48 & 64 & 65 & 75 \\
\hline Zn-binding protein, $\mathrm{BH} 0713$ & 73 & 91 & 91 & 93 \\
\hline \multicolumn{5}{|l|}{ Flagellar proteins } \\
\hline Flagellin, BH0147 & 91 & 90 & 90 & 93 \\
\hline GAPDH $\ddagger$, BH0057 & 92 & 95 & 96 & 97 \\
\hline GlpQ\$, BH0241B & - & 81 & 82 & 89 \\
\hline Ef-Tu, BH0476 & 94 & 97 & 97 & 97 \\
\hline Fructose-bisphosphate aldolase, $\mathrm{BH} 0445$ & 88 & 93 & 93 & 96 \\
\hline Triosephosphate isomerase, $\mathrm{BH} 0055$ & 77 & 86 & 86 & 91 \\
\hline Phosphoglycerate mutase, BH0658 & 83 & 90 & 91 & 96 \\
\hline \multicolumn{5}{|l|}{ Immune evasion protein } \\
\hline Factor H-binding protein, EF411143* & - & - & - & 61 \\
\hline \multicolumn{5}{|l|}{ Proteins with unknown function } \\
\hline Hypothetical, FJ446703* & - & 46 & 47 & 58 \\
\hline Hypothetical, BH0238* & 53 & 72 & 73 & 83 \\
\hline
\end{tabular}

${ }^{\star}$ Proteins identified as unique within the Borrelia genus.

$\dagger$ Oligopeptide permease homologue.

‡Glyceraldehyde-3-phosphate dehydrogenase.

$\S$ Glycerophosphodiester phosphodiesterase. 


\section{B. hermsii database analysis and amino acid identity of proteins reactive with immune IgM}

Proteins identified by mass spectrometry were grouped into eight categories where, except for Vsps, protein plugs containing an individual protein are shown (Table 1). Given that several Vsps were identified within a protein plug, mapping peptides identified by mass spectrometry to their respective Vsp confirmed that unique peptides were identified from each Vsp (data not shown).

While 114 protein samples were analysed by mass spectrometry, identifying the same protein in several spots was common. This could be due to post-translational modifications including lipidation of the identified variable membrane proteins and several of the $\mathrm{ABC}$ transporter proteins (Bono et al., 1998; Burman et al., 1990; Kornacki \& Oliver, 1998; Shang et al., 1998). Also, protein binding to residual DNA and RNA could cause heterogeneous protein migration.

Amino acid alignments of non-variable membrane proteins indicated the conserved nature of the identified proteins when compared to B. hermsii (Table 2). Similar to GlpQ and the factor $\mathrm{H} /$ plasminogen-binding protein (FhbA) (Hovis et al., 2006; Rossmann et al., 2007; Schwan et al., 1996), no orthologue of hypothetical protein FJ446703 was identified in Borrelia burgdorferi (Table 2). Additionally, BLAST analysis identified P66, FhbA, and hypothetical proteins FJ446703 and $\mathrm{BH} 0238$ as unique proteins within the genus Borrelia.

\section{Comparisons of IgM-reactive protein candidates between human patients and mice infected with B. hermsii}

Immunoblot comparisons confirmed similar IgM profiles in human patients and mice infected with $B$. hermsii, where

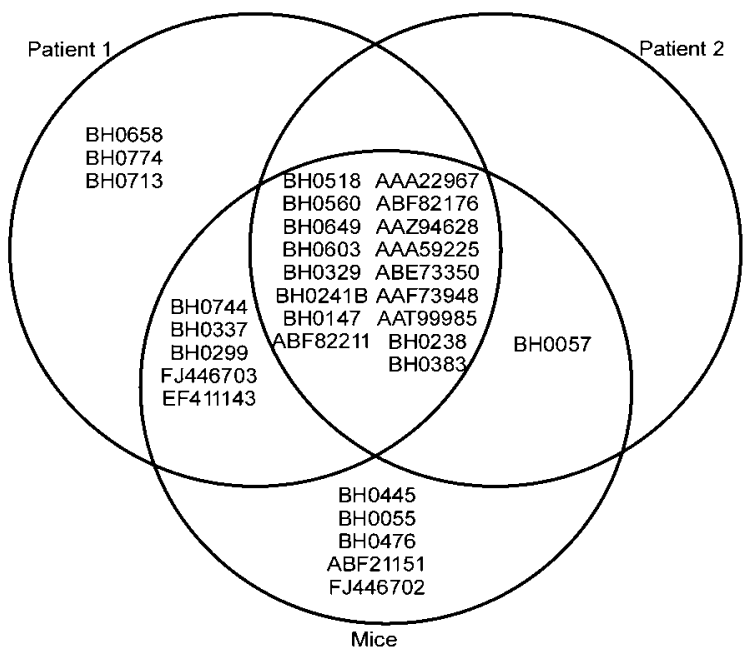

Fig. 2. Venn diagram demonstrating the reactivity of human and murine $\lg \mathrm{M}$ against $B$. hermsii proteins. Most proteins were recognized by IgM from both human patients and mice.
$74 \%$ of the protein spots were recognized by both human and mouse serum samples (Fig. 2). In addition, lack of IgM reactivity to Vlp 5 from human serum samples was likely due to the expression of other $v l p s$ during their infection.

\section{IgM reactivity to rGIpQ during early $B$. hermsii and $B$. recurrentis infection}

Murine and human IgM bound to rGlpQ during early spirochaete infection (Figs 3 and 4). Murine IgM bound to rGlpQ at the expected molecular mass by the fourth day after spirochaete infection (Fig. 3A), and prior to detection of IgG antibodies (Fig. 3B), while preimmune serum was negative to the antigens tested (Fig. 3C).

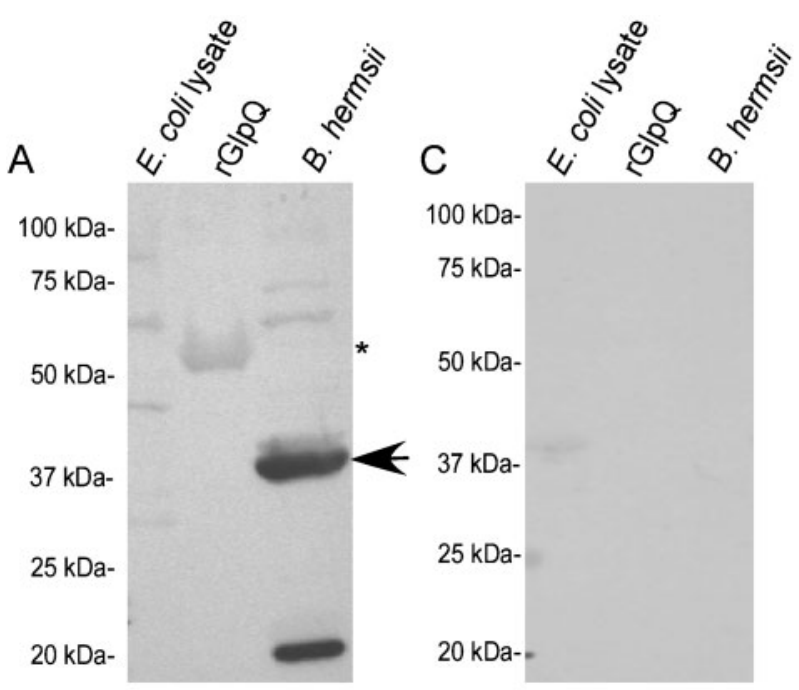

B

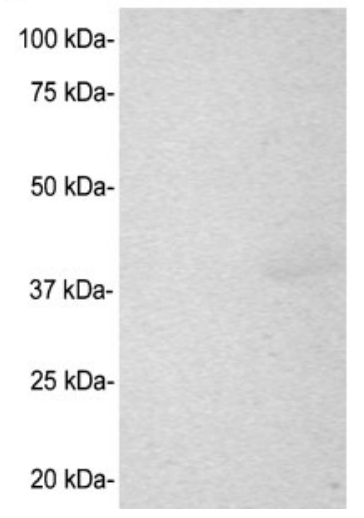

Fig. 3. Detection of IgM to rGlpQ during early $B$. hermsii infection. Murine IgM reactivity was detected to $\mathrm{rGlpQ} 4$ days after infection $(A)$, while an $\lg G$ response (B) and preimmune serum were negative to $E$. coli lysate, rGlpQ and $B$. hermsii (C). The arrow indicates the observed molecular mass of native GlpQ, while the asterisk indicates the molecular mass of rGlpQ. Molecular mass standards are shown on the left of each immunoblot. 
IgM binding to rGlpQ was detected in acute-phase serum samples from eight of 15 Ethiopian patients infected with B. recurrentis (Fig. 4). In addition, these serum samples were negative when previously tested for IgG responses against rGlpQ (Porcella et al., 2000).

\section{Expression and immunogenicity of rBH0238}

Given the conserved nature of BH0238, its apparent immunogenicity in $B$. hermsii, and preliminary data suggesting that its orthologue is immunogenic in $B$. recurrentis (data not shown), this gene was expressed as a potential diagnostic antigen. Inducing transformed E. coli with a final concentration of $0.2 \%$ arabinose produced a protein band at the expected molecular mass of $48 \mathrm{kDa}$ (Fig. 5A). Immunoblotting with an anti-polyhistidine $\mathrm{mAb}$ confirmed reactivity with a protein at $48 \mathrm{kDa}$ and $35 \mathrm{kDa}$, suggesting degradation of rBH0238 (Fig. 5B). In addition, there was no mAb reactivity in uninduced E. coli (Fig. 5B).

Immunoblotting confirmed the immunogenicity of rBH0238 in mice (Fig. 6A). Convalescent serum from Ethiopian patients infected with $B$. recurrentis reacted with rBH0238 while their acute serum did not (Fig. 6B). Reactivity to a protein at approximately $37 \mathrm{kDa}$ in acute serum samples $1 \mathrm{~A}$ and $4 \mathrm{~A}$ suggests reactivity to the immunogenic protein flagellin (Fig. 6B) (Barbour et al., 1986, 2008; Coleman \& Benach, 1989; Collins \& Peltz, 1991; Schneider et al., 1992).

\section{DISCUSSION}

The results reported here are from the first comprehensive identification of $B$. hermsii protein candidates that are bound by immune IgM. Furthermore, identifying the previously reported immunogenic proteins GlpQ, FhbA, flagellin, Vtp, Vsps and Vlps (Barbour et al., 1986; Colombo \& Alugupalli, 2008; Hovis et al., 2006; Porcella et al., 2000; Schwan et al., 1996; Shang et al., 1998) suggested that $2 \mathrm{D}$ electrophoresis and immunoblotting was an adequate method for identifying protein candidates that are reactive with IgM. In addition, while P66, DnaK, P93 and GAPDH (glyceraldehyde-3-phosphate dehydrogenase) are reactive with serum generated against $B$. burgdorferi (Anda et al., 1994, 1996; Bunikis et al., 1996, 1998; Coleman \& Benach, 1992), we report that these proteins are also immunogenic during $B$. hermsii infection. Interestingly, in B. burgdorferi, DnaK, P93 and GAPDH are detected by the same IgM monoclonal antibody (Anda et al., 1994, 1996); however, it is unknown if these proteins were identified in this study due to a common epitope.

Of the immunoreactive protein candidates identified, heatshock, $A B C$ transporter and housekeeping proteins have been reported as immunostimulators in other organisms (Bercic et al., 2008; Brown et al., 2001; Bunk et al., 2008; Da'dara et al., 2008; Delvecchio et al., 2006; Garmory \& Titball, 2004; Granato et al., 2004; Harland et al., 2007; Jomaa et al., 2005; Lewthwaite et al., 2002, 2001, 2007;

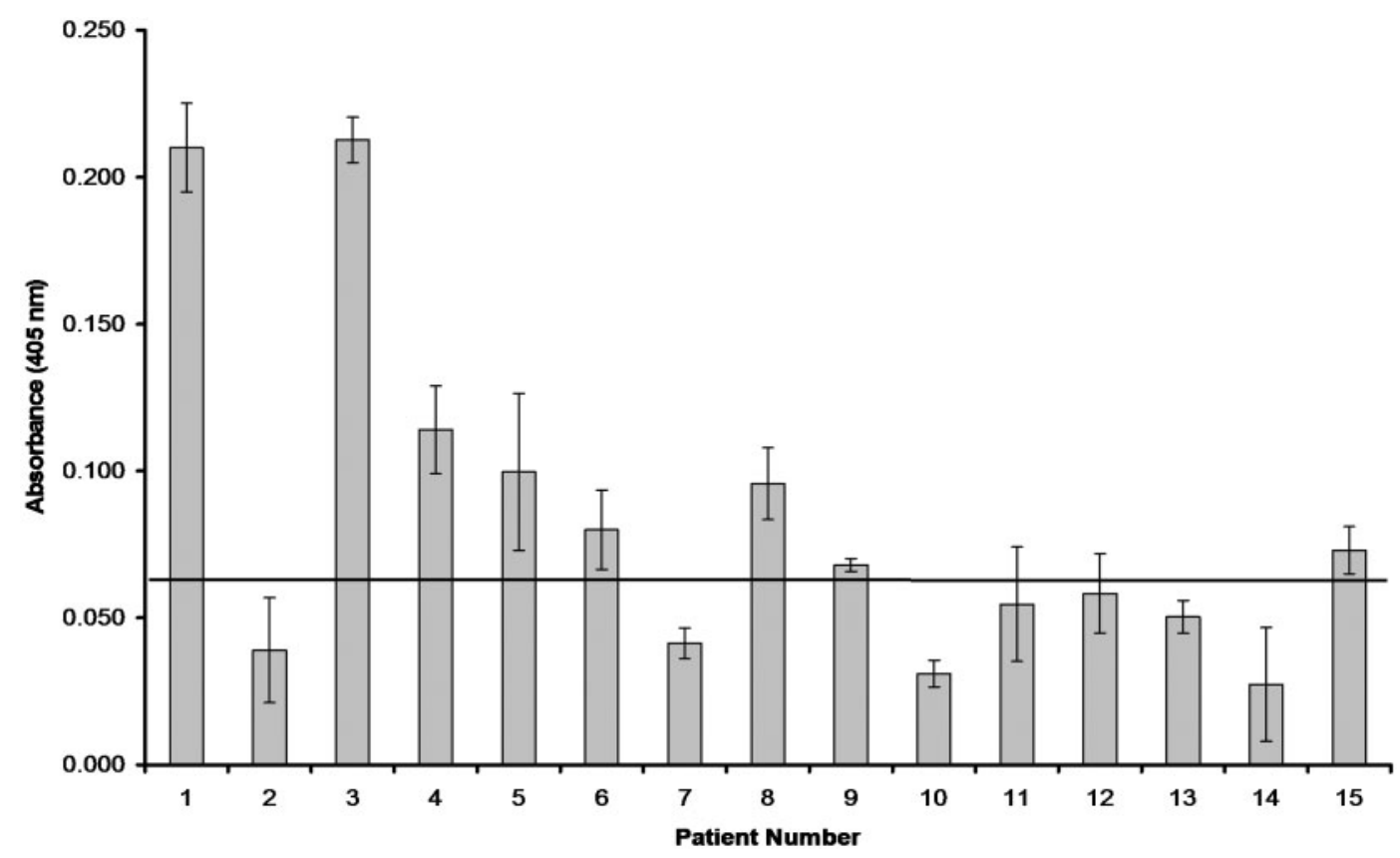

Fig. 4. An ELISA measuring IgM binding to rGIpQ using acute-phase serum samples from 15 Ethiopian patients infected with $B$. recurrentis. The standard deviation of each mean is indicated with error bars, and the horizontal line represents the threshold for determining a positive sample with a $P \leqslant 0.003$. 


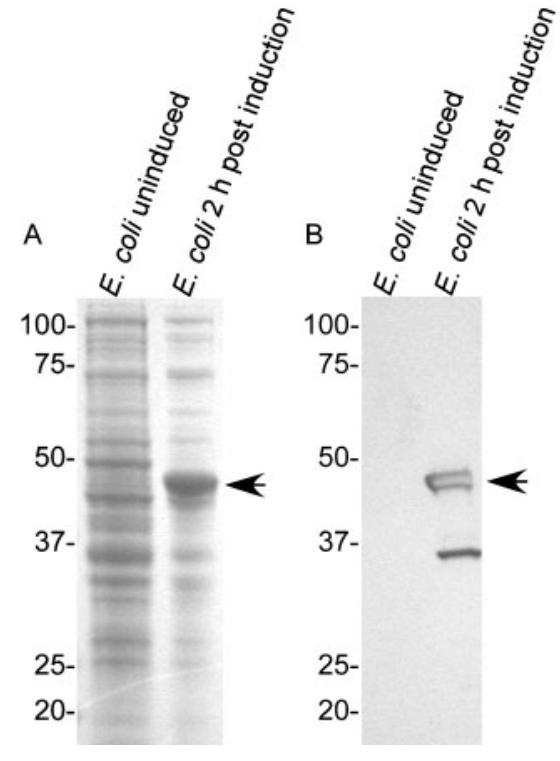

Fig. 5. Production of $\mathrm{rBH} 0238$. Coomassie-stained gel $(\mathrm{A})$ and an immunoblot (B) probed with an anti-polyhistidine $\mathrm{mAb}$ of uninduced and induced $E$. coli. The arrowheads indicate protein bands of the expected size for $\mathrm{rBH} 0238$.
Ratnakar et al., 1996; Sellman et al., 2005; Shah \& Swiatlo, 2006; Tanabe et al., 2006; Tanghe et al., 1999). For example, the adjuvant properties of DnaK aid in protecting against Schistosoma japonicum infection when delivered as a DNA-based vaccine (Da'dara et al., 2008). The protective capacity of $A B C$ transporter proteins is observed in mice, animals immunized with OppA being more resistant to Yersinia pestis infection compared to control mice (Tanabe et al., 2006). While the surface localization of various heatshock, $\mathrm{ABC}$ transporter and housekeeping proteins has been determined in other bacteria (Balasubramanian et al., 2008; Delepelaire, 2004; Frisk et al., 1998; Frisk \& Lagergard, 1998; Huesca et al., 1996; Lewthwaite et al., 1998, 2002, 2001, 2007; Ratnakar et al., 1996; Yamaguchi et al., 1996), our attempts to confirm surface localization of these proteins were inconclusive.

An additional objective of our study was to determine early IgM reactivity to rGlpQ (Porcella et al., 2000). In mice, IgM reactivity to $\mathrm{rGlpQ}$ was detected within 4 days of spirochaete infection. Furthermore, IgM responses to rGlpQ were detected from eight additional patients infected with $B$. recurrentis. While promising, these results also suggest the importance of identifying additional immunogens for early detection of relapsing fever spirochaetes, especially for infections where the organisms are below the level of detection.

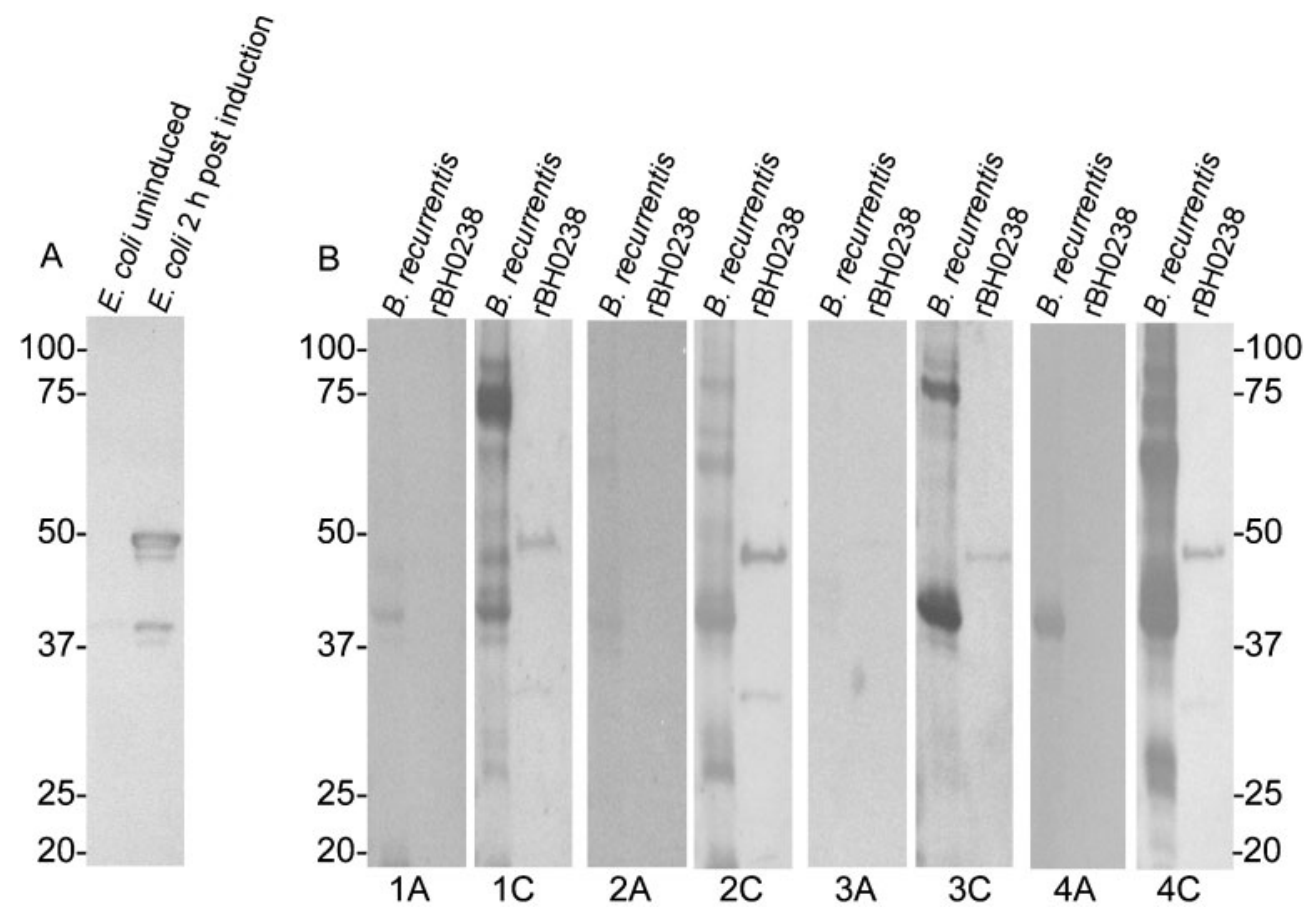

Fig. 6. Serum reactivity against $\mathrm{rBH} 0238$ using serum samples from mice infected with $B$. hermsii (A) or from patients infected with $B$. recurrentis $(B)$. Immunoblots were probed with acute-phase serum samples (labelled $A$ under $B$. recurrentis immunoblots) or with convalescent-phase serum samples (labelled C). Molecular mass standards (kDa) are shown next to each immunoblot. 
Three diagnostic antigens of interest include FhbA (Hovis et al., 2006), and hypothetical proteins FJ446703 and $\mathrm{BH} 0238$. The factor H-binding protein and hypothetical protein FJ446703 could be diagnostic antigens in North America because they discriminate between relapsing fever spirochaetes and Lyme-disease-causing spirochaetes. While rBH0238 was recognized with serum from patients infected with $B$. recurrentis, studies indicate that patients with Lyme disease also seroconvert to this antigen (data not shown), limiting $\mathrm{rBH} 0238$ as an antigen that could discriminate between the two species of Borrelia. However, given this protein's immunogenicity and BLAST analysis indicating that it is a Borrelia-specific protein, combining rBH0238 with additional immunogens may aid in diagnosing infection of relapsing fever spirochaetes.

Two factors complicating the treatment of relapsing fever patients include high spirochaete counts associated with a poorer prognosis (Melkert, 1991) and the reported misdiagnosis of relapsing fever Borrelia (Nordstrand et al., 2007). Collectively, the data reported here identify proteins whose immunogenic properties can be further investigated and may be useful for early serodiagnosis. In addition, these findings may aid in managing relapsing fever Borrelia in endemic regions and have the potential to alleviate healthcare costs in developing countries.

\section{ACKNOWLEDGEMENTS}

We thank B. Joseph Hinnebusch and Philip E. Stewart for reviewing this manuscript, Anita Mora and Gary Hettrick for photographic assistance, Robert A. Heinzen for use of his 2D electrophoresis equipment, Glen A. Nardone for his technical expertise, and Robert J. Hohman for his logistic support. This work was supported by the Division of Intramural Research, NIAID, NIH.

\section{REFERENCES}

Alugupalli, K. R. (2008). A distinct role for B1b lymphocytes in T cell-independent immunity. Curr Top Microbiol Immunol 319, 105130.

Alugupalli, K. R., Gerstein, R. M., Chen, J., Szomolanyi-Tsuda, E., Woodland, R. T. \& Leong, J. M. (2003a). The resolution of relapsing fever borreliosis requires IgM and is concurrent with expansion of B1b lymphocytes. J Immunol 170, 3819-3827.

Alugupalli, K. R., Michelson, A. D., Joris, I., Schwan, T. G., HodivalaDilke, K., Hynes, R. O. \& Leong, J. M. (2003b). Spirochete-platelet attachment and thrombocytopenia in murine relapsing fever borreliosis. Blood 102, 2843-2850.

Alugupalli, K. R., Leong, J. M., Woodland, R. T., Muramatsu, M., Honjo, T. \& Gerstein, R. M. (2004). B1b lymphocytes confer T cellindependent long-lasting immunity. Immunity 21, 379-390.

Anda, P., Backenson, P. B., Coleman, J. L. \& Benach, J. L. (1994). Epitopes shared by unrelated antigens of Borrelia burgdorferi. Infect Immun 62, 1070-1078.

Anda, P., Gebbia, J. A., Backenson, B., Coleman, J. L. \& Benach, J. L. (1996). A glyceraldehyde-3-phosphate dehydrogenase homolog in Borrelia burgdorferi and Borrelia hermsii. Infect Immun 64, 262268.
Balasubramanian, S., Kannan, T. R. \& Baseman, J. B. (2008). The surface-exposed carboxyl region of Mycoplasma pneumoniae elongation factor-Tu interacts with fibronectin. Infect Immun 76, 31163123.

Barbour, A. G. (1984). Isolation and cultivation of Lyme disease spirochetes. Yale J Biol Med 57, 521-525.

Barbour, A. G. (1990). Antigenic variation of a relapsing fever Borrelia species. Annu Rev Microbiol 44, 155-171.

Barbour, A. G. \& Bundoc, V. (2001). In vitro and in vivo neutralization of the relapsing fever agent Borrelia hermsii with serotype-specific immunoglobulin $\mathrm{M}$ antibodies. Infect Immun 69, 1009-1015.

Barbour, A. G. \& Hayes, S. F. (1986). Biology of Borrelia species. Microbiol Rev 50, 381-400.

Barbour, A. G., Hayes, S. F., Heiland, R. A., Schrumpf, M. E. \& Tessier, S. L. (1986). A Borrelia-specific monoclonal antibody binds to a flagellar epitope. Infect Immun 52, 549-554.

Barbour, A. G., Dai, Q., Restrepo, B. I., Stoenner, H. G. \& Frank, S. A. (2006). Pathogen escape from host immunity by a genome program for antigenic variation. Proc Natl Acad Sci U S A 103, 18290-18295.

Barbour, A. G., Jasinskas, A., Kayala, M. A., Davies, D. H., Steere, A. C., Baldi, P. \& Felgner, P. L. (2008). A genome-wide proteome array reveals a limited set of immunogens in natural infections of humans and white-footed mice with Borrelia burgdorferi. Infect Immun 76, 3374-3389.

Battisti, J. M., Raffel, S. J. \& Schwan, T. G. (2008). A system for sitespecific genetic manipulation of the relapsing fever spirochete Borrelia hermsii. Methods Mol Biol 431, 69-84.

Belperron, A. A., Dailey, C. M. \& Bockenstedt, L. K. (2005). Infectioninduced marginal zone B cell production of Borrelia hermsii-specific antibody is impaired in the absence of CD1d. J Immunol 174, 56815686.

Bercic, R. L., Slavec, B., Lavric, M., Narat, M., Bidovec, A., Dovc, P. \& Bencina, D. (2008). Identification of major immunogenic proteins of Mycoplasma synoviae isolates. Vet Microbiol 127, 147-154.

Bono, J. L., Tilly, K., Stevenson, B., Hogan, D. \& Rosa, P. (1998). Oligopeptide permease in Borrelia burgdorferi: putative peptidebinding components encoded by both chromosomal and plasmid loci. Microbiology 144, 1033-1044.

Brown, J. S., Ogunniyi, A. D., Woodrow, M. C., Holden, D. W. \& Paton, J. C. (2001). Immunization with components of two iron uptake ABC transporters protects mice against systemic Streptococcus pneumoniae infection. Infect Immun 69, 6702-6706.

Bryceson, A. D., Parry, E. H., Perine, P. L., Warrell, D. A., Vukotich, D. \& Leithead, C. S. (1970). Louse-borne relapsing fever. Q J Med 39, 129-170.

Bunikis, J., Noppa, L., Ostberg, Y., Barbour, A. G. \& Bergström, S. (1996). Surface exposure and species specificity of an immunoreactive domain of a 66-kilodalton outer membrane protein (P66) of the Borrelia spp. that cause Lyme disease. Infect Immun 64, 51115116.

Bunikis, J., Luke, C. J., Bunikiene, E., Bergström, S. \& Barbour, A. G. (1998). A surface-exposed region of a novel outer membrane protein (P66) of Borrelia spp. is variable in size and sequence. J Bacteriol 180, 1618-1623.

Bunk, S., Susnea, I., Rupp, J., Summersgill, J. T., Maass, M., Stegmann, W., Schrattenholz, A., Wendel, A., Przybylski, M. \& Hermann, C. (2008). Immunoproteomic identification and serological responses to novel Chlamydia pneumoniae antigens that are associated with persistent C. pneumoniae infections. J Immunol 180, 5490-5498. 
Burgdorfer, W. (1951). Analyse des Infektionsverlaufes bei Ornithodorus moubata (Murray) und der naturlichen Uebertragung von Spirochaeta duttoni. Acta Trop 8, 194-262.

Burman, N., Bergström, S., Restrepo, B. I. \& Barbour, A. G. (1990). The variable antigens Vmp7 and Vmp21 of the relapsing fever bacterium Borrelia hermsii are structurally analogous to the VSG proteins of the African trypanosome. Mol Microbiol 4, 1715-1726.

Buxton, P. A. (1946). The Louse. An Account of the Lice Which Infest Man, Their Medical Importance and Control, 2nd edn. Baltimore: Williams \& Wilkins.

Coffey, E. M. \& Eveland, W. C. (1967). Experimental relapsing fever initiated by Borrelia hermsi. II. Sequential appearance of major serotypes in the rat. J Infect Dis 117, 29-34.

Coleman, J. L. \& Benach, J. L. (1989). Identification and characterization of an endoflagellar antigen of Borrelia burgdorferi. J Clin Invest 84, 322-330.

Coleman, J. L. \& Benach, J. L. (1992). Characterization of antigenic determinants of Borrelia burgdorferi shared by other bacteria. J Infect Dis 165, 658-666.

Collins, C. \& Peltz, G. (1991). Immunoreactive epitopes on an expressed recombinant flagellar protein of Borrelia burgdorferi. Infect Immun 59, 514-520.

Colombo, M. J. \& Alugupalli, K. R. (2008). Complement factor Hbinding protein, a putative virulence determinant of Borrelia hermsii, is an antigenic target for protective Blb lymphocytes. J Immunol 180, 4858-4864.

Connolly, S. E., Thanassi, D. G. \& Benach, J. L. (2004). Generation of a complement-independent bactericidal IgM against a relapsing fever Borrelia. J Immunol 172, 1191-1197.

Da'dara, A. A., Li, Y. S., Xiong, T. \& ZhouJWilliams, G. M., McManus, D. P., Feng, Z., Yu, X. L., Gray, D. J. \& Harn, D. A. (2008). DNA-based vaccines protect against zoonotic schistosomiasis in water buffalo. Vaccine 26, 3617-3625.

Dai, Q., Restrepo, B. I., Porcella, S. F., Raffel, S. J., Schwan, T. G. \& Barbour, A. G. (2006). Antigenic variation by Borrelia hermsii occurs through recombination between extragenic repetitive elements on linear plasmids. Mol Microbiol 60, 1329-1343.

Delepelaire, P. (2004). Type I secretion in gram-negative bacteria. Biochim Biophys Acta 1694, 149-161.

Delvecchio, V. G., Connolly, J. P., Alefantis, T. G., Walz, A., Quan, M. A., Patra, G., Ashton, J. M., Whittington, J. T., Chafin, R. D. \& other authors (2006). Proteomic profiling and identification of immunodominant spore antigens of Bacillus anthracis, Bacillus cereus, and Bacillus thuringiensis. Appl Environ Microbiol 72, 6355-6363.

Dworkin, M. S., Schwan, T. G. \& Anderson, D. E. (2002). Tickborne relapsing fever in North America. Med Clin North Am 86, 417433.

Felsenfeld, O. (1971). Borrelia. Strains, Vectors, Human and Animal Borreliosis. St Louis, MO: Warren H. Green, Inc.

Frisk, A. \& Lagergard, T. (1998). Characterization of mechanisms involved in adherence of Haemophilus ducreyi to eukaryotic cells. APMIS 106, 539-546.

Frisk, A., Ison, C. A. \& Lagergard, T. (1998). GroEL heat shock protein of Haemophilus ducreyi: association with cell surface and capacity to bind to eukaryotic cells. Infect Immun 66, 1252-1257.

Garmory, H. S. \& Titball, R. W. (2004). ATP-binding cassette transporters are targets for the development of antibacterial vaccines and therapies. Infect Immun 72, 6757-6763.

Granato, D., Bergonzelli, G. E., Pridmore, R. D., Marvin, L., Rouvet, M. \& Corthesy-Theulaz, I. E. (2004). Cell surface-associated elongation factor Tu mediates the attachment of Lactobacillus johnsonii NCC533
(La1) to human intestinal cells and mucins. Infect Immun 72, 21602169.

Harland, D. N., Chu, K., Haque, A., Nelson, M., Walker, N. J., SarkarTyson, M., Atkins, T. P., Moore, B., Brown, K. A. \& other authors (2007). Identification of a LolC homologue in Burkholderia pseudomallei, a novel protective antigen for melioidosis. Infect Immun 75, 4173-4180.

Hayes, L. J., Wright, D. J. M. \& Archard, L. C. (1988). Segmented arrangement of Borrelia duttonii DNA and location of variant surface antigen genes. J Gen Microbiol 134, 1785-1793.

Hovis, K. M., Schriefer, M. E., Bahlani, S. \& Marconi, R. T. (2006). Immunological and molecular analyses of the Borrelia hermsii factor $\mathrm{H}$ and factor $\mathrm{H}$-like protein 1 binding protein, FhbA: demonstration of its utility as a diagnostic marker and epidemiological tool for tickborne relapsing fever. Infect Immun 74, 4519-4529.

Huesca, M., Borgia, S., Hoffman, P. \& Lingwood, C. A. (1996). Acidic $\mathrm{pH}$ changes receptor binding specificity of Helicobacter pylori: a binary adhesion model in which surface heat shock (stress) proteins mediate sulfatide recognition in gastric colonization. Infect Immun 64, 2643-2648.

Jomaa, M., Yuste, J., Paton, J. C., Jones, C., Dougan, G. \& Brown, J. S. (2005). Antibodies to the iron uptake ABC transporter lipoproteins PiaA and PiuA promote opsonophagocytosis of Streptococcus pneumoniae. Infect Immun 73, 6852-6859.

Kornacki, J. A. \& Oliver, D. B. (1998). Lyme disease-causing Borrelia species encode multiple lipoproteins homologous to peptide-binding proteins of ABC-type transporters. Infect Immun 66, 4115-4122.

Lewthwaite, J., Skinner, A. \& Henderson, B. (1998). Are molecular chaperones microbial virulence factors? Trends Microbiol 6, 426-428.

Lewthwaite, J. C., Coates, A. R., Tormay, P., Singh, M., Mascagni, P., Poole, S., Roberts, M., Sharp, L. \& Henderson, B. (2001). Mycobacterium tuberculosis chaperonin 60.1 is a more potent cytokine stimulator than chaperonin 60.2 (Hsp 65) and contains a CD14binding domain. Infect Immun 69, 7349-7355.

Lewthwaite, J., George, R., Lund, P. A., Poole, S., Tormay, P., Sharp, L., Coates, A. R. \& Henderson, B. (2002). Rhizobium leguminosarum chaperonin 60.3 , but not chaperonin 60.1 , induces cytokine production by human monocytes: activity is dependent on interaction with cell surface CD14. Cell Stress Chaperones 7, 130-136.

Lewthwaite, J. C., Clarkin, C. E., Coates, A. R., Poole, S., Lawrence, R. A., Wheeler-Jones, C. P., Pitsillides, A. A., Singh, M. \& Henderson, B. (2007). Highly homologous Mycobacterium tuberculosis chaperonin 60 proteins with differential CD14 dependencies stimulate cytokine production by human monocytes through cooperative activation of p38 and ERK1/2 mitogen-activated protein kinases. Int Immunopharmacol 7, 230-240.

Melkert, P. W. (1991). Mortality in high risk patients with tick-borne relapsing fever analysed by the Borrelia-index. East Afr Med J 68, 875879.

Newman, K., Jr \& Johnson, R. C. (1984). T-cell-independent elimination of Borrelia turicatae. Infect Immun 45, 572-576.

Nordstrand, A., Bunikis, I., Larsson, C., Tsogbe, K., Schwan, T. G., Nilsson, M. \& Bergström, S. (2007). Tickborne relapsing fever diagnosis obscured by malaria, Togo. Emerg Infect Dis 13, 117-123.

Porcella, S. F., Raffel, S. J., Schrumpf, M. E., Schriefer, M. E., Dennis, D. T. \& Schwan, T. G. (2000). Serodiagnosis of louse-borne relapsing fever with glycerophosphodiester phosphodiesterase (GlpQ) from Borrelia recurrentis. J Clin Microbiol 38, 3561-3571.

Ratnakar, P., Rao, S. P. \& Catanzaro, A. (1996). Isolation and characterization of a $70 \mathrm{kDa}$ protein from Mycobacterium avium. Microb Pathog 21, 471-486. 
Restrepo, B. I., Kitten, T., Carter, C. J., Infante, D. \& Barbour, A. G. (1992). Subtelomeric expression regions of Borrelia hermsii linear plasmids are highly polymorphic. Mol Microbiol 6, 3299-3311.

Rossmann, E., Kraiczy, P., Herzberger, P., Skerka, C., Kirschfink, M., Simon, M. M., Zipfel, P. F. \& Wallich, R. (2007). Dual binding specificity of a Borrelia hermsii-associated complement regulatoracquiring surface protein for factor $\mathrm{H}$ and plasminogen discloses a putative virulence factor of relapsing fever spirochetes. J Immunol 178, 7292-7301.

Schneider, T., Lange, R., Ronspeck, W., Weigelt, W. \& Kolmel, H. W. (1992). Prognostic B-cell epitopes on the flagellar protein of Borrelia burgdorferi. Infect Immun 60, 316-319.

Schwan, T. G. \& Piesman, J. (2002). Vector interactions and molecular adaptations of Lyme disease and relapsing fever spirochetes associated with transmission by ticks. Emerg Infect Dis 8, 115-121.

Schwan, T. G., Kime, K. K., Schrumpf, M. E., Coe, J. E. \& Simpson, W. J. (1989). Antibody response in white-footed mice (Peromyscus leucopus) experimentally infected with the Lyme disease spirochete (Borrelia burgdorferi). Infect Immun 57, 3445-3451.

Schwan, T. G., Schrumpf, M. E., Hinnebusch, B. J., Anderson, D. E. \& Konkel, M. E. (1996). GlpQ: an antigen for serological discrimination between relapsing fever and Lyme borreliosis. J Clin Microbiol 34, 2483-2492.

Schwan, T. G., Battisti, J. M., Porcella, S. F., Raffel, S. J., Schrumpf, M. E., Fischer, E. R., Carroll, J. A., Stewart, P. E., Rosa, P. \& Somerville, G. A. (2003). Glycerol-3-phosphate acquisition in spirochetes: distribution and biological activity of glycerophosphodiester phosphodiesterase (GlpQ) among Borrelia spirochetes. J Bacteriol 185, 1346-1356.
Sellman, B. R., Howell, A. P., Kelly-Boyd, C. \& Baker, S. M. (2005). Identification of immunogenic and serum binding proteins of Staphylococcus epidermidis. Infect Immun 73, 6591-6600.

Shah, P. \& Swiatlo, E. (2006). Immunization with polyamine transport protein PotD protects mice against systemic infection with Streptococcus pneumoniae. Infect Immun 74, 5888-5892.

Shang, E. S., Skare, J. T., Exner, M. M., Blanco, D. R., Kagan, B. L., Miller, J. N. \& Lovett, M. A. (1998). Isolation and characterization of the outer membrane of Borrelia hermsii. Infect Immun 66, 1082-1091.

Southern, P. M. \& Sanford, J. P. (1969). Relapsing fever: a clinical and microbiological review. Medicine 48, 129-149.

Stoenner, H. G., Dodd, T. \& Larsen, C. (1982). Antigenic variation of Borrelia hermsii. J Exp Med 156, 1297-1311.

Tanabe, M., Atkins, H. S., Harland, D. N., Elvin, S. J., Stagg, A. J., Mirza, O., Titball, R. W., Byrne, B. \& Brown, K. A. (2006). The ABC transporter protein OppA provides protection against experimental Yersinia pestis infection. Infect Immun 74, 3687-3691.

Tanghe, A., Lefèvre, P., Denis, O., D'Souza, S., Braibant, M., Lozes, E., Singh, M., Montgomery, D., Content, J. \& Huygen, K. (1999). Immunogenicity and protective efficacy of tuberculosis DNA vaccines encoding putative phosphate transport receptors. J Immunol 162, 1113-1119.

Yamaguchi, H., Osaki, T., Taguchi, H., Hanawa, T., Yamamoto, T. \& Kamiya, S. (1996). Flow cytometric analysis of the heat shock protein 60 expressed on the cell surface of Helicobacter pylori. J Med Microbiol 45, 270-277.

Edited by: R. J. Lamont 